\title{
Preliminary Survey of Timber Yielding Plants of Bhadravathi Taluk, Karnataka
}

\author{
Dr. K.Harish Kumar ${ }^{1}$, Dr. B.R.Kiran ${ }^{2}$ \\ ${ }^{1}$ Department of Environmental Science, Government First Grade College, Hoskote, Bangalore Rural \\ district, Karnataka \\ ${ }^{2}$ Research \& Teaching Assistant in Environmental Science, DDE, Kuvempu University, \\ Shankaraghatta, Karnataka, India
}

\begin{abstract}
The present study is based on the preliminary survey on timber yielding plant resources of Bhadravathi taluk, Karnataka during 2012-2013. The study reports on 27 timber yielding plants belonging to 25 genera and 13 families, along with their utility. Among plant families Fabaceae is dominant with 9 species followed by Moraceae and Myrtaceae with 4 and 3 species respectively. Peoples of this area possess good knowledge of plants used for different purposes, but their continuous exposure to modernization may result in extinction of the species.
\end{abstract}

Keywords: Timber resources, Utility, Bhadravathi taluk, Karnataka

\section{INTRODUCTION}

Human beings are depending on the plants for food, shelter and medicine. Besides this wood had considerable importance in the livelihood of ancient people, use of wood in making several things such as agricultural implements, boat building, handicrafts, packing cages, toys, construction, furniture, instruments, turnery, carving, etc (Ambasta, 1992 ; Anonymous, 1948-1976 ; Asolkar, et al., 1992; Vijigiri Dinesh and Sharma. 2012).

Plants are useful to man in many ways. All the parts of the plant are useful to mankind. Plants provide us food, wood for furniture, raw materials for clothing and housing. The wood obtained from plants is used mainly for the construction of houses and making furniture. This wood is called as timber (https://www.learnnext.com, 2013).

The main aim of the present study has been to know the diversity of timber yielding plant species in Bhadravathi taluk of Karnataka.

\section{Materials ANd Methods}

Bhadravati is a taluk headquarter situated in the Shimoga District of Karnataka state, India. It is located at a distance of about 20 kilometers from the district headquarter Shimoga. Bhadravathi is located at Latitude- $13^{\circ} 52^{\prime} \mathrm{N}$ and Longitude- $75^{\circ} 40^{\prime} \mathrm{E}$.

For the documentation of information and collection of plant material, several field visits were undertaken in non-forest areas during the period 2012 -2013. Data presented here is based on personal observations and methodology used is based on the standard methods (Jain and Rao, 1997; Jain, 1999 ; Jain, 1989 ; Jain and Mudgal,1999; Sharma and Singh,2001; Singh and Subramanyam,2008; Vijigiri Dinesh and Sharma, 2012).The collected plant specimens were identified with the help of recent and relevant floras and confirmed from the authentic specimens. Plant specimens with their botanical names with their family are depicted in Table 1.

Table1. Utility of Timber Yielding Plants in the Study Area

\begin{tabular}{|l|l|l|l|}
\hline Sl.No & Scientific Name & Family & Utility/Usage \\
\hline 1 & Acacia auriculiformis & Fabaceae & $1,2,3$ \\
\hline 2 & Areca catechu & Arecaceae & 1,3 \\
\hline 3 & Artocarpus heterophyllus & Moraceae & $1,2,3$ \\
\hline 4 & Aegle marmelos & Rutaceae & 3,4 \\
\hline 5 & Azadirachta indica & Meliaceae & $1,2,3,5$ \\
\hline
\end{tabular}


Dr. K.Harish Kumar \& Dr. B.R.Kiran

\begin{tabular}{|l|l|l|l|}
\hline 6 & Butea monosperma & Fabaceae & 3 \\
\hline 7 & Bauhinia purpurea & Fabaceae & $2,3,4$ \\
\hline 8 & Bauhinia variegata & Fabaceae & $2,3,4$ \\
\hline 9 & Bambusa sp. & Poaceae & $1,2,3$ \\
\hline 10 & Cocos nucifera & Arecaceae & 1,3 \\
\hline 11 & Cassia fistula & Fabaceae & 1,3 \\
\hline 12 & Delonix regia & Fabaceae & 2,3 \\
\hline 13 & Dalbergia latifolia & Fabaceae & 2,3 \\
\hline 14 & Eugenia jambulana & Myrtaceae & 1,3 \\
\hline 15 & Eucalyptus sp. & Myrtaceae & 2,3 \\
\hline 16 & Ficus reliogiosa & Moraceae & 3,5 \\
\hline 17 & Ficus benghalensis & Moraceae & 3 \\
\hline 18 & Michelia champaca & Magnoliaceae & 2,3 \\
\hline 19 & Mangifera indica & Anacardiaceae & 3,5 \\
\hline 20 & Morus alba & Moraceae & 1,4 \\
\hline 21 & Phyllanthus emblica & Phyllanthaceae & 1,3 \\
\hline 22 & Pongamia pinnata & Fabaceae & 1 \\
\hline 23 & Psidium guajava & Myrtaceae & $1,3,4$ \\
\hline 24 & Santalum album & Santalaceae & 2,3 \\
\hline 25 & Tamarindus indica & Fabaceae & 2 \\
\hline 26 & Tectona grandis & Lamiaceae & $1,2,3,4$ \\
\hline 27 & Terminalia arjuna & Combretaceae & $1,2,3$ \\
\hline
\end{tabular}

Note: 1: Agricultural implements 2: Furniture 3: House construction 4 : Poles/ sticks 5: Packing Boxes

\section{Results AND Discussion}

The present study reports on 27 timber yielding plants belonging to 25 genera and 13 families, along with their utility. Among plant families Fabaceae is dominant with 9 species followed by Moraceae and Myrtaceae with 4 and 3 species respectively (Figure 1). Information gathered from Bhadravathi taluk indicates that the peoples of this region utilize wood resources for various purposes (Table 1. and Fig. 2).

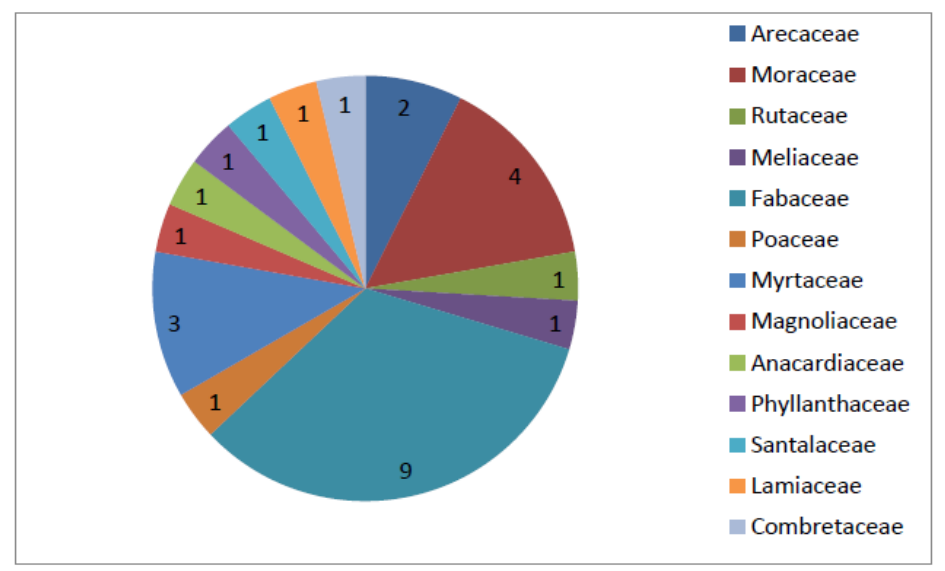

Figure1. Number of Timber Yielding Plants in Each Family

The present study confirms about the effective and efficient use of various tree species like Bambusa sp., Acacia auriculiformis, Azadirachta indica, Bauhinia variegata, Bauhinia purpurea, Pongamia pinnata, Tectona grandis,Mangifera indica, Azadirachta indica, Tectona grandis and Terminalia arjuna are used for house construction, manufacturing of agricultural implements and also for making furniture's.

Ficus religiosa and Ficus benghlensis are used during house construction. Cocos nucifera used as poles, furniture and as formwork in concrete construction. The Mangifera indica is well known for its fruits. It is moderately strong. It is most often used for cheap furniture, toys, packing boxes, cabinet work, panels for doors and for windows (en.wikipedia.org).

Tectona grandis is durable and fire-resistant. It can be easily seasoned and worked. It takes up a good polish and is not attacked by white ants and dry rot. It does not corrode iron fastenings and it shrinks little. It is among the most valuable timber trees of the world and its use is limited to superior work only. Acacia sp is used for such products as bodies and wheels of bullock cart, agricultural instruments, tool handles, furniture's and well curbs (en.wikipedia.org). 


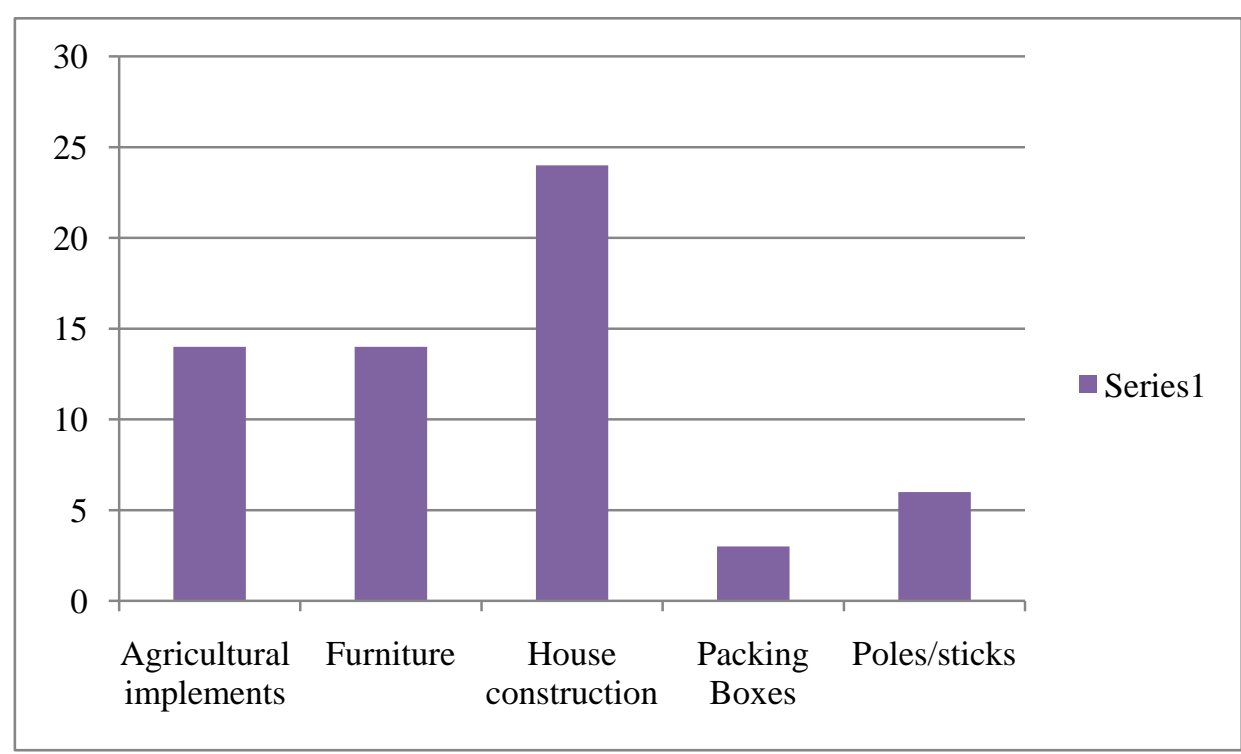

Figure2. Plants Utility for Different Purposes

Many trees were very old and appear to be carefully conserved by the peoples looking to the benefits such as small timber for construction and agricultural purposes, fuel wood, fruits, fodder and other benefits rendered by trees (Shivanna et al.,2005). Species such as Ficus religiosa was attached with religious sentiments and they were conserved with great care.

\section{Conclusion}

Timber yielding plant species are important for the human beings and sustenance of life. These trees are used for house construction, manufacturing of agricultural implements, packing boxes, sticks and also for making furniture's. The documentation and appropriate utilization of timber yielding plants and traditional knowledge need scientific management and utilization. Peoples of this area possess good knowledge of plants used for different purposes, but their continuous exposure to modernization may result in extinction of the species in future.

\section{REFERENCES}

[1] Ambasta, S. P.1992. The useful Plants of India, Publication \&Information Directorate, CSIR, New Delhi

[2] Anonymous. 1948-1976.The Wealth of India- Raw Materials, Vol.I - XI. Publication and Information Diectorate, New Delhi

[3] Asolkar, L. V., Kakkar, K. K. and Chakra, O. J. 1992. Second supplement to glossary of Indian Medicinal plants with Active principles. Part I (A-K), (1965-81). Publications \& Information Directorate, CSIR, New Delhi.

[4] https://en.wikipedia.org

[5] https://www.learnnext.com/nextgurukul/wiki/concept/Uttar-Pradesh/VII/Biology/Plants---Fibreand-Timber.htm.2013.

[6] Jain S.K. and Rao R.R. 1997., Field and Herbarium Methods. Today and Tomorrow's Printers and Publishers, New Delhi.

[7] Jain, S. K. (ed.). 1989. Methods and approaches in Ethno-botany, Society of Ethno botanists, Luknow.

[8] Jain, S. K. 1999. Dictionary of Ethno veterinary Plants of India, Deep Publications, New Delhi.

[9] Jain, S. K. and V. A. Mudgal. 1999. A Handbook of Ethno-botany, Bhisensingh Mahendrapal Singh, Dehradun.

[10] Sharma, P. P. and Singh, N. P. 2001. Ethno-botany of Dadra Nagar Haveli and Daman, (Union Territories), Botanical Survey of India, Kolkata.

[11] Shivanna,H.,Parasurama Janagiri and Sanjeev Kyatappanavar.2005.Enumeration of Tree Species in Farm Lands of Gadag District of Karnataka. Karnataka J.Agric.Sci.,18 (3): 850-853.

[12] Singh H.B. and Subramanyam.2008. Field manual of Herbarium Techniques NISCAIR (CSIR) New Delhi-12.

[13] Vijigiri Dinesh and P. P. Sharma. 2012. Timber yielding plants and their utilities in Nizamabad district of Andhra Pradesh. Journal of Phytology 2012, 4(4): 17-20 


\section{AUTHORS' BIOGRAPHY}

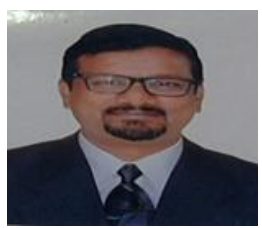

Dr. K. Harish Kumar, is currently working as Assistant Professor in the Department of Environmental Science, Government First Grade College, Hoskote562114, Bangalore Rural district, Karnataka, obtained his M.Sc. and Ph.D in Environmental Science from Kuvempu University, Karnataka. He has published many articles in International and National journals. He has attended number of Conference, seminars, Symposium and workshops.

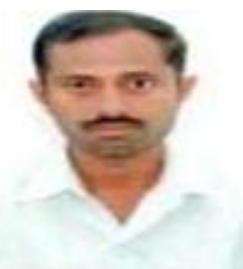

Dr. B.R. Kiran, working as Research and Teaching Assistant in the Department of Environmental Science, DDE, Kuvempu University, Shankaraghatta( Karnataka) and obtained his M.Sc., M.Phil and Ph.D in Environmental Science from Kuvempu University, Karnataka. He has published many papers in International and National journals. He has attended number of Conference, seminars, Symposium and science and society. workshops. He is the recipient of several prestigious awards for his contribution to 